\title{
新疆平原沙漠区湖泊干缩现象的初步评价
}

\author{
王晓峰 \\ 章海生

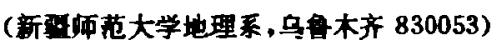 \\ (南京大学大地海洋科学系, 南京 210008)
}

提要对新闻平原少湖泊干缩现象作了初步评价，指出这一现象是干旱、半干旱地区

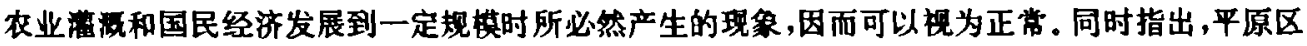
湖泊之存亡既取决于自然条件，更取决于社会经济发展的需要。现存湖泊资源的开发与保护，既要 立足于生态环境价值论,也要立足于经济价值论。

关词内陆湖泊 平原少湖泊干缩初步评价

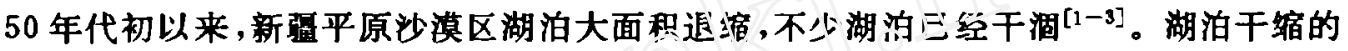
原因主要是人类引水灌源所致。笔者曾对湤泊干路的生空效应作了初步探讨 ${ }^{[4]}$, 本文拟在此 基础上从社会、经济、自然等方面对上述测染㴼现象作一初步的综合评价。

\section{1 评价原则}

在审视新疆平原沙漠区湖泊干缩所引起的一系列变化的同时, 既要看到其有害的一面, 也要看到其有利的一面。人类要发展, 不可能不干预自然; 人类要更好地发展, 不可以不保护 自然。矢量人类活动好坏优少与否的主要方法是权衡利整。笔者认为, 在评价地区性生态环 境变化时,应莩循如下原则:

（1）综合性原则。即不仅要考虑到湖区生态环境的变化给人类带来的直接或间接的损 失, 也要考虑到湖泊所在流域水土资源开发给人类带来的收益; 不仅要看到湖泊局地环境的 变化, 也要看到流域环境的变化; 既要看到流域自然环境的变化状况, 也要看到区域经济、社 会的岸展状说。

（2）历史性原则。即不仅要看到湖区现在的生态环境状况, 也要考察历史上生态环境的 演变过程,现代生态环境是在过去的基础上发展而来的。对于历史上曾经发生过的直接或间 接影响到湖区环境的各种人类活动, 应放在当时的社会、经济、政治和文化条件下去考察, 而 不宜只用现行标准和现行观念来衡量。

（3）生产力标准原则。即衡量区域生态环境是否优少的主要标准是该区区域生产力发 展水平, 以及在末来可预见的时期内, 生产力水平能否持续提高。干旱区地区性生态环境的 变化是与地区生产力的发展水平密切相关的, 它既是地区生产力发展的后果之一, 又主要取 决于生产力的发展。

收稿日期: 1993 年 6 月 11 日接受日期: 1993 年 8 月 21 日。 
（4）国情或区情原则。环境问题作为学术研究是没有界限的,但牵涉到政策差异时则可 能受到国界和区界的限制。某区域的某种环境变化是否被枧为一种环境问题, 与如何评价和 采取何种对策是两个不同的问题, 主要原因在于各国或各地区生产力发展水平的差异。换言 之,国情不同,或地区区情不同,对同一种生态环境问题可能作出不同的评价和对策。

基于上述原则，笔者对新嘼平原沙漠区湖泊干缩现象作出如下评价。

\section{2 对湖泊干缩现象的基本评价}

\section{1 湖泊干缩在干早、半干旱区普遍存在}

随着灌溉规模的扩大和工农业需水量的增加，干旱、半干旱区平原沙漠地区的湖泊必然 趋于缩小和干涸。这种现象不是新疆独有的, 我国西北干旱、半干旱区普遍存在有这种现

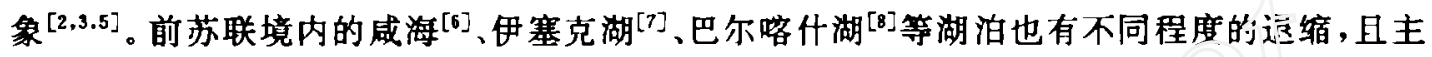
要原因都是引水灌涯。造成这种现象在干旱区普遍存在的主要鿌因是

(1) 人口的增长和经济的发展要求不断扩大枅地面积. 尤其是在㨁一流域开发的最初 二、三十年内,耕地面积几乎呈直线增长。

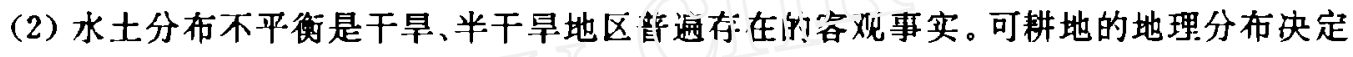
了水资源的利用方向。农业发展要沗办土达到较等组合, 干旱区可耕地资源一般都位于湖泊 上游地区，水资源的调欧方向目河也波指向湖泊上游。干旱区许多流域土地资源开发重心不 断由下游向上、中游传移即枈有力的佐证,而水利工程为这种转移提供了可能性。

（3）干旱区水资淙的有限性和干旱区湖泊几乎全部都位于河流终点这两个特点, 决定 了在同一流域内扩大篧面积和保持原有湖水面二者不可同时兼顾。只有吞吐性湖泊所在 流域才能在一定程度上兼顾这两方面。

由此可见,在干旱、半干旱地区,在人类大规模开发活动的影响下,湖泊干缩具有必然 性,因而可以枧为一种正常现象。

\section{2 湖泊退缩或消失在我国非干早、半干早区所独有}

湖泊大面积退缩或消失也不仅仅是干旱、半干早地区独有的现象。纵观我国 50 年代以 来湖泊的变化情况, 可以发现, 湖泊大面积退缩不仅发生在蒙新干旱、半干旱地区, 也同样发 生在湿润多雨的东部平原地区。据研究, 50 年代初至 70 年代末, 全国大于等于 $1 \mathrm{~km}^{2}$ 的湖泊 个数由 2800 多个减少到 2300 个左右, 湖泊总面积由 $89627 \mathrm{~km}^{2}$ 下降到 $70988 \mathrm{k} \mathrm{m}^{2}$ 。其中长江 中下游平原及淮河流域湖泊面积减少 $11991 \mathrm{~km}^{2}$, 蒙新地区退缩 $5644 \mathrm{~km}^{2}$ (主要发生在平原 少漠区), 分别占全国总退缩面积的 $64.33 \%$ 和 $30.28 \%{ }^{[0.10]}$ 。尽管湿洞地区湖泊大面积消失 的主要原因是围星和泥少湤积, 但引起湖泊大面积退缩或消失的社会、经济原因是相同的, 即都表现为对短缺资源的过度追求与开发。在干旱区表现为对水资源的开发利用; 在湿润区 表现为对土地资源 (尤其是耕地资源)的追求与开发。对短缺资源的开发都大大提高了资源 的利用率和经济价值,同时也带来了相应的生态环境问题。因此, 尽管我们现在还不能说平 原区湖泊的存在完全取决于社会、经济因䒬，但这种趋势在我国是表现得越来越明显。

\section{3 湖泊干缩在新至有其特殊的历史背景及缘由}

新留平原沙漠区湖泊干缩现象是在 50 年代以来大规模星荒的历史背景下发生的。当时 
各圼区几乎都是白手起家,这就决定了开发初期的生产过程是一种粗放式的简单再生产过 程, 因此,人们不可能对这种生产活动可能带来的种种环境问题作出预测。退一步说，即使能 繁作出预测，也无法避免由此产生的大部分环境问题。中星是中国历代政府治国安邦的一项 基本政策,这不仅是出于政治需要,也是出于经济需要。50 年代以来新疆维吾尔自治区的星 荒规模大大超过了历史上任何一个时期, 它既反映了是荒的必然性和继承性, 也反映厂新中 国成立以来新疆水土资源开发的一般过程。

\section{4 湖泊不再处于纯天然状梞,均受人类活动影响}

不论是干旱区还是湿润区,现在平原区湖泊都已不再处于纯天然状态,对湖泊进行水库 化改造已被证明是提高天然湖泊的生态、经济价值的较好方法,甚至可能是唯一的方法。而 能否进行水库化改造,则主要取决于湖泊所处的地理位置以及人类赋予湖泊的各种生态和 经济功能。新疆平原沙漠区湖泊均位于河流尾闾，一般均处于所在流域的最低注处,除个别 湖泊 (如博斯腾湖、吉力湖)尚能保持一定的吞吐能力外，其余湖泊 (包括已于涸的湖泊)均为

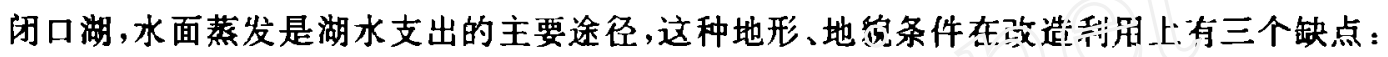

（1）无论怎样改造，湖泊都无法具备水库所具有的一一㳍功能(调青示源、供水等)。

（2）湖水处于不断威化状态。由于盐分不排人，湖路自然沉积外没有别的出路 (除 人工开发盐湖或湖泊水生物资源而使部分移出)。臣说，除个别吞吐湖(如吉力湖)外,其余湖 泊无一例外地已演变成威衣湖。

（3）受、游人强方利活动的影响很大。一方面，上游引水会使湖泊退缩，湖水浓缩; 另一

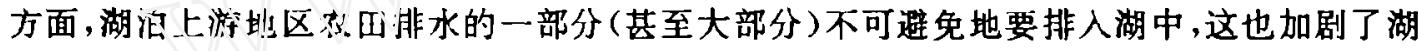
水的威化速距。而湖水矿化度达到一定程度时，湖泊将不再具有经济价值(除盐矿资源外)。 上述特点决定了人类对这类湖泊进行水库化改造利用的极端困难性。

\section{5 湖泊干缩的同时,水库在增多}

在天然湖泊干缩的同时, 新生的人工湖泊一一水库星罗棋布于平原地区和山区。从 1950 年到 1992 年,全晅共建成各类水库 490 余座,总库容大于 $60 \times 10^{8} \mathrm{~m}^{3}$, 水库水面积 $2000 \mathrm{~km}^{2}$ 左右。水库较之于河流尾间湖,其相对于人类需求的各种生态和经济功能有了明显 提高。主要表现在:

（1）水库使水资源得到了更有效的利用，它不同程度地根据人类的需求调节了水资源 的时空分布状态,大大缓解了不少流域水十分布不平衡的矛盾，同时也为水力资源的开发提 供了一定的保证。

(2) 它使人类大大提高了抗湖自然炎害的能力,为农业生产和经济建设持续稳定地发 展提供了必要的保证。

(3) 库区经济有了不同程度的发展。因此,仅以天然湖泊面积的增减来看待湖泊干缩现 象是没有多大意义的。

\section{6 湖泊干缩会导致一系列生态环境问题}

2.6.1 土地沙漠化 湖泊干缩所引起的沙漠化土地在新疆大面积沙漠化土地中仅占很小 的比例。新疆近 2000 年米人类活动时期沙漠化土地面积为 $3.05 \times 10^{4} \mathrm{k} \mathrm{m}^{2}$, 占全国沙漠化土 地面积的 $17.27 \%$ 。其中古尔班通古特沙漠边缘为 $0.63 \times 10^{4} \mathrm{k} \mathrm{m}^{2}$, 塔克拉玛干沙漠边缘为

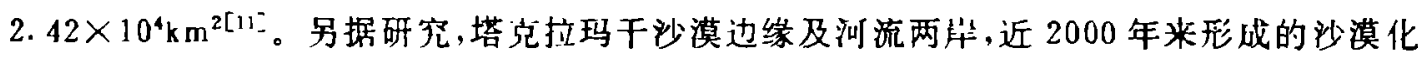


土地面积为 $2.83 \times 10^{4} \mathrm{k} \mathrm{m}^{2}$, 其中近百年来形成的现代少漠化土地面积为 $0.86 \times 10^{4} \mathrm{~km}^{2}$ (其 中有 $0.73 \times 10^{4} \mathrm{~km}^{2}$ 为就地起少),占沙化总面积的 $30.3 \%$ 。在现代沙漠化土地中,由于水资 源利用不合理形成的沙漠化土地为 $3430 \mathrm{~km}^{2}$, 约占现代少化土地面积的 $40 \%{ }^{[12]}$ 。这个比例

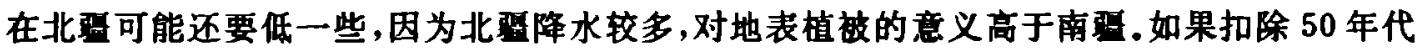
大规模星荒已形成的少化土地，则这一比重就更小。水资源利用不当的后果表现为多种形 式,如河道干涸，湖泊干缩，灌溉不当后弃耕等等。湖泊干缩只是其后果之一。

2.6.2植物物种消失在已知的因湖泊干缩而消失的各种植物中，没有一种是湤危植物或 农作物野生亲缘种(这两类植物被国际社会列入优先保护之列)。尽管我们承认没有一种植 物不重要，没有一种植物不应该得到保护。但同时也应当承认，对生物物种的保持宜有轻重 缓急之分, 已消失的植物目前并未对人类造成不可挽回的后果。新鼠已建成的各类自然保护 区中,没有一个保护区包含有平原沙漠区湖泊。这也从某一方面反映了其相对生态价值。

2.6.3生物资源利用纵观我国经济发达地区和世界发达国家湖泊生物资济河开发过程，

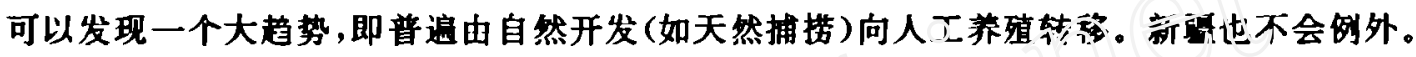

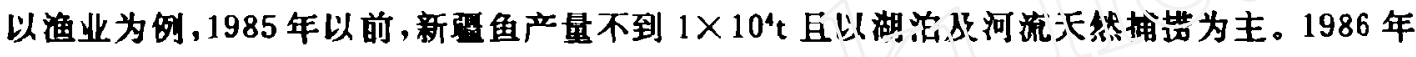

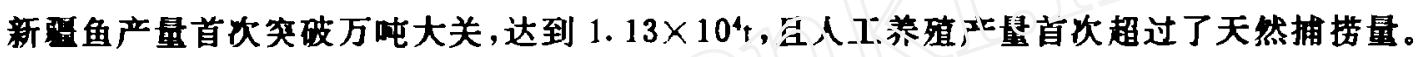

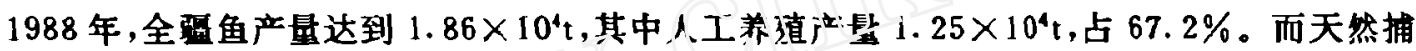
楛量从 1960 年的 $5700 \mathrm{t}$ 增加到 1985 年的 $6100 \mathrm{t}$, 几乎没有什么增长 ${ }^{[13]}$ 。只要新留市场需求

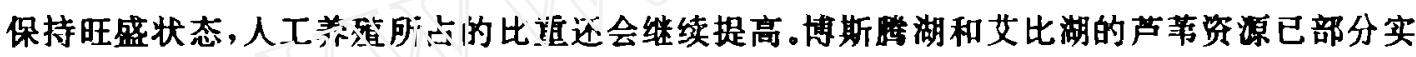

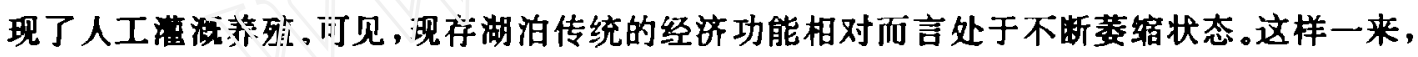
保护现存湖泊的经济方面的理由也就必然处于不断倨化状态。

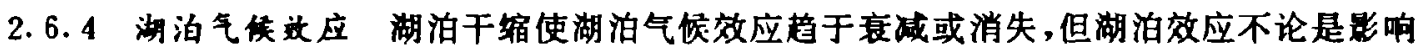
范围还是影响强度都是较为有限的 ${ }^{[14]}$ 。另一方面, 由于湖泊所在流域大面积流溉, 也产生了 相应的气候效应。据研究，在干旱区大面积灌激可导致由于热力强迫作用产生的一个性质上 非常类似于海风环流的潮湿土塙风环流，在该环流的作用下，使该地区从干早气侯向较为湿 润的气候方向调整 ${ }^{[15]}$ 。另据研究，与土裹热力状况的影响相比,土售水在短期气侯变化中起 着重要的作用，气娭异常 (对干旱区来说,这往往意味著持续干旱等灾害性天气)的持续性与 地一气之间水分及能量交换的能力有关; 土壤湿度或植被醍盖度越大，则地一气水分和热量交 换的速度越快, 从而地一气系统扰动衰减的速度也越块。在较干的气候环境中,地-气系统自 身调节能力较㖨，因而扰动容易维持 ${ }^{[16.17]}$ 。据此推论，绿洲区内由于兴修水库和大面积灌源 以及大面积植树造林，土壤水状况及植被螵盖度均大大优于绿洲区外，因此绿洲区内气侯环 境会得到不同程度的改善。

\section{7 湖泊干缩的同时, 绿洲面积大楅增加}

在新望土地大面积沙化的同时,绿洲面积也在大幅度地增加, 从1949年的 $1.7 \times$ $10^{4} \mathrm{~km}^{2}$ 增加到目前的 $5.87 \times 10^{4} \mathrm{k} \mathrm{m}^{2}$, 象增 $4.17 \times 10^{4} \mathrm{~km}^{2[13]}$. 比近 2000 年来形成的沙漠化 土地面积(3.05 × $\left.10^{4} \mathrm{~km}^{2}\right)$ 还要多 $1.12 \times 10^{4} \mathrm{~km}^{2}$ 。可见,50年代以来的绿洲化面积远远大于 同期沙化面积。不仅如此，二者的经济、生态意义迥然不同。绿洲是干旱区人民进行生产、生 活活动的主要基地,绿洲面积的稳定扩大与否是新桯经济能否持续发展的前提条件之一。新

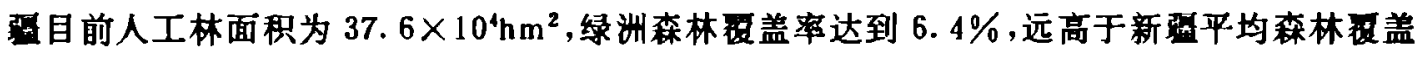




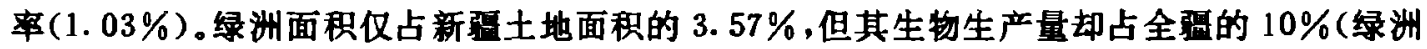
和全㤱生物生产量分别为 $714 \mathrm{t} / \mathrm{km}^{2}$ 和 $\left.321 \mathrm{t} / \mathrm{km}^{2}\right)$ 。新晋目前约 $95 \%$ 的人口居住在绿洲区。 绿洲的扩大和建设也使绿洲区内小气候环境有了改善。以石河子市为例, 该市是在荒滩上建 设起来的典型绿洲，现绿化票盖率达 $36.7 \%$;市区与奴区相比，同一时期内，风速降低 $40 \%$ ， 大风先成少 $60 \%$, 蒸发量诚少 $21.7 \%$, 日温差缩小 $4.1 \mathrm{C}$, 空气相对显度提高 $21.9 \%$ $25 \%{ }^{[12]}$ 。由此可见,稳定和扩大绿洲面积是干旱区水土资源开发的一条必由之路。但是绿洲 的稳定与扩大几乎完全依赖水资源的稳定供给。在一定经济技术条件下,可利用水资源量是 有限的,由此面临着一个非常现实的问题: 有限的水资源, 是将其用来扩大绿洲面积, 还是顺 其自然使之流入少漠或河流尾间湖? 对于那些密切关注自己生存环境的干旱区各级政府和 人民来说，做出前一种选择是理所当然的。

\section{8 生态环境问题不仅仅与社会经济发展因害有关}

人类目前所面临的四类生态环境问题(污染、物种灭绝、区域生态环塝恶化、全球环境变

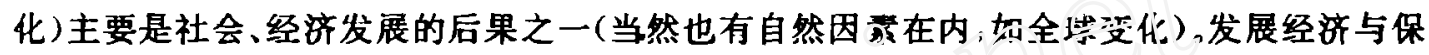

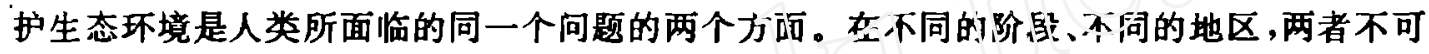
避免地产生矛盾，但两者的根本目标是一致的，叨不断提忘人类的生存能力和生活质量。某

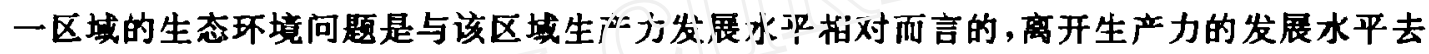
谈区域生态环境问题是没考多大隹义的：

新中国成立 50 旁年来,新留大规模的水利活动在带来一些生态环境问題的同时,也带 来了经济相对㷛荣属面。主要表现在:

(1)人!有了很大增长。由 1949 年的 433 万人增加到 1992 年的 1560 万人(据 1990 年 人口普查数据推算)。

（2）生产力水平有了很大提高。1992 年全疆工农业总产值达到 474 亿元, 其中工业总产 值 295 亿元; 国民生产总值达到 333. 亿元, 人均 2134.6 元, 高于全国平均水平(以上均为 1990 年不变价)。耕地面积由 1949 年的 $1.2093 \times 10^{4} \mathrm{hm}^{2}$ 增加到 1992 年的 $3.4 \times 10^{4} \mathrm{hm}^{2}$ 左 右。农业生产已连续 15 年丰产, 桹食总产量由 1949 年的 $84.77 \times 10^{4} \mathrm{t}$ 增加到 1992 年的 $694.3 \times 10^{4} \mathrm{t}$ 要。农业的持续稳定发展为以农副产品为原料的加工工业的发展奠定了良好的 基础。1988 年, 以农副产品为原料的加工工业总产值占工业总产值的 $39.4 \%{ }^{[13]}$ 。农业及其 加工工业的发展为其它工业的发展积累了大量的发展算金。

\section{9 现存湖泊仍处于不稳定的暂时均衡状态}

新翼平原沙漠区湖泊之所以还能保存至今，是湖泊所在流域人地关系尚末达到非常恶 劣的程度，或虽还保持有一定的水面，但已丧失其基本生态功能。前者如博斯湖、布伦托 海、吉力湖、文比湖, 后者如艾西曼湖、艾丁湖和巴里坤湖等。前一类湖泊生态用水由于湖泊 所在流域水资源相对丰富, 采取适当工程措施后, 湖泊生态用水仍能在一定水平上达到供需 平衡,尽管没有一个湖泊能够保持 50 年代初的水平。博斯腾湖所在的开都河流域年地表水 资源量为 $35 \times 10^{8} \mathrm{~m}^{3}$ 左右, 而工农业引水量为 $13 \times 10^{8} \mathrm{~m}^{3}$ (1989 年); 故面积退缩不大, 80 年 代以后的水位下降主要出于炏化湖水的需要, 1989 年宝浪苏木水利枢纽工程建成后, 湖水 
位又有所回升。布伦托海和吉力湖所在的乌伦古河流域年河川径流量为 $10 \times 10^{8} \mathrm{~m}^{3}$ 左右,但 沿途工农业引水量及河道输水损失量早已超出此数，是故湖泊趋于退缩.由于邻近的尔京 斯河流域水贺源丰富，采取适当的引水措施后，两湖湖水位均饮复到 60 年代初的水平。新尔 齐斯河流域和乌伦古河流域年地表水资源总量约 $130 \times 10^{8} \mathrm{~m}^{3}$, 但到 1984 年仅引用 $32 \times$ $10^{8} \mathrm{~m}^{3}$, 且浪费很大。艾比湖流域的 $37.46 \times 10^{8} \mathrm{~m}^{3}$ 年地表水资源量中已被引用 $20.38 \times 10^{8} \mathrm{~m}^{3}$ (1985 年),导致相应湖面面积大为退缩。

整个 80 年代, 新疆耕地面积的增长和引水量的增加幅度都很小, 加之对湖泊采取了不 少保护措施，平原沙漠区湖泊基本上处于稳定状态。由此可见，湖泊的现存状态是流域水土 资源开发规模和湖泊生态用水在一定范围内取得暂时均行的一种不稳定状态，其末来的命 运仍将受到流域水土资源开发活动的影响,这一点和过去并没有太大的区别。

\section{3 结 语}

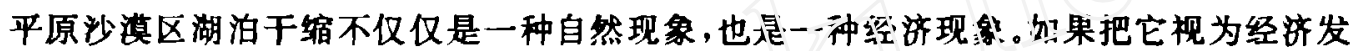

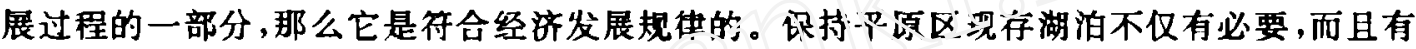
可能。必要性在于：(1)保持干旱区的生物:样性; (2) 分事湖区资源开发仍有较为可观的经 济收益; (3)在目前条件下，某些湖洁(如博斯酶湖)仍具有一些人工方式西时还无法取代的

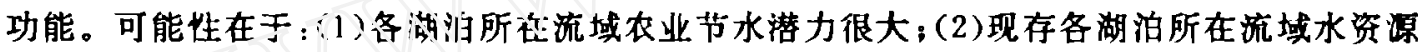
相对丰富; (3)现枌治:泊都已程度不同地采取了工程保护措施。

新弱平原区现存湖泊末来的命运既取决于各流域淮等水利事业的发展,也取决于新

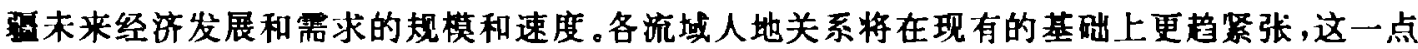
应引起有关部门的注意。

\section{考文献}

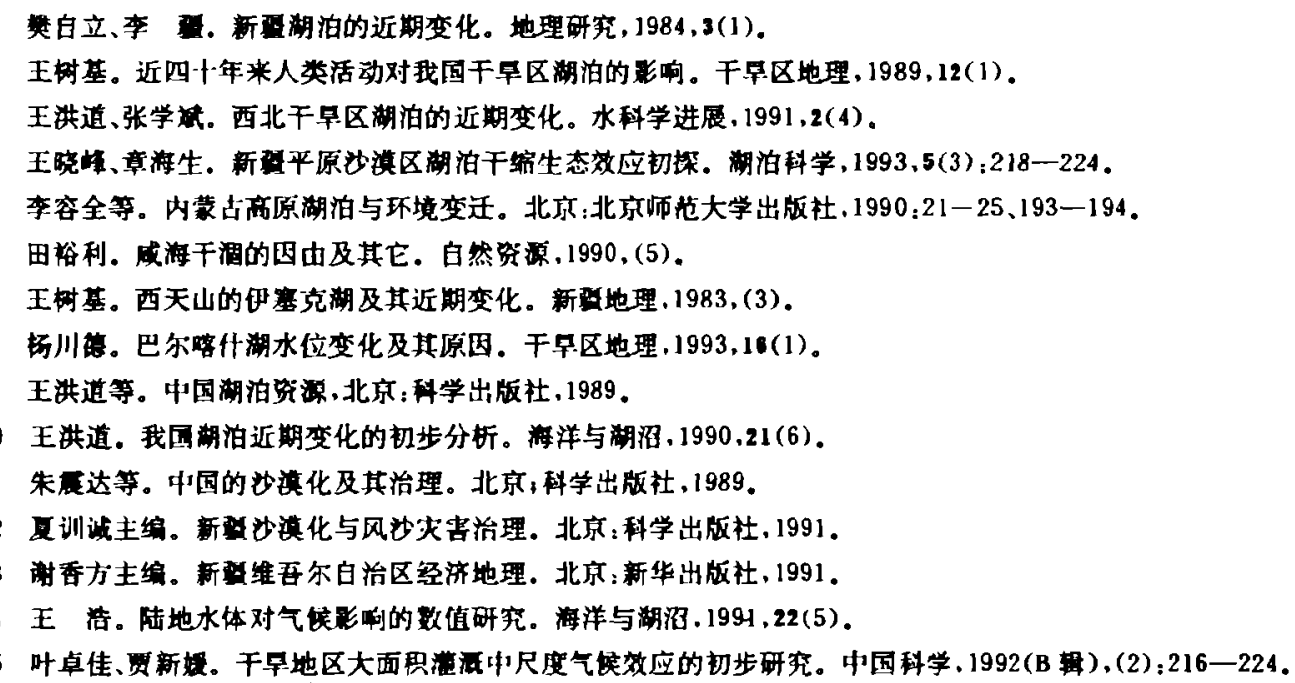




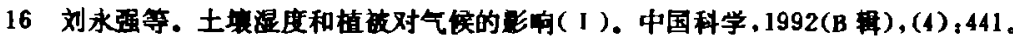

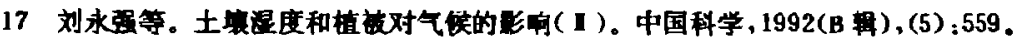

\title{
PRELIMINARY EVALUATION ON THE SHRINK AGE AND DRIED-UP OF LAKES IN PLAIN AND DESERT AREAS IN XINJIANG PROVINCE
}

\author{
Wang Xiaofeng ${ }^{1}$ \\ Zhang Haisheng ${ }^{2}$ \\ (1) Department of Geopraphy, Xinjiang Normal U miverdity, Urugi 830053, \\ 2 Departmeat of Geo and Ocean Sciences, Nax $\ddot{m} g$ Unipersiy, Nan jag 210008)
}

\begin{abstract}
Most lakes in Xinjiang Province have been sirrinking considerabiy ince the 1950s, especially in plain and desert areas, and some have even dried up. T'ise lake shrinkage took place on account of large-scale reclamatior, and was as inevitable outcome of the economic development and the expansion of irigation ariss $\mathrm{i}$ arid and semi-arid lands. The reasons are as follows: (1) The proulacion increase and economic development require the expansion of cultivated arez. (i) The istribution of arable lands determines water resources utilization. (3) It is trouvlescme to balance the expansion of irrigation area and the maintenance of lake area simultaneously because of limited water resources and lake locations.

That whether the eco-environment of the whole watershed is ameliorated and the regional productive power is improved should be regarded as the standard to evaluate the effects of lake shrinkage mentioned above. Many reservoirs have been built in the upstream area of lakes as the lakes shrinked or dried-up downstream. Large-scale irrigation and afforestation have alleviated the local climate, especially in oasis areas. The ratio of water resources utilization is greatly improved by constructing water projects. The oasis areas are expanded more rapidly than the losses of desertation as the productivity of asis areas steadly grows. Human powers to prevent and mitigate natural disasters (such as flood and drought) have been strengthened in almost every watershed of Xinjiang Province. The sustainable and stable growth of agriculture has promoted the economy and provided a favorable basis for further development.

It is necessary and possible to protect the existing lakes in plain areas. The fate of them depends not only upon natural conditions and evolutions, but also upon the need of economic development. Consequently, the utilization and conservation of lake resources should take the eco-environmental factors as well as economic ones into consideration.
\end{abstract}

Key Words Inland lakes, plain and desert areas, shrinkage and dried-up of lakes, preliminary evaluation 